研究室紹介

\section{東京工科大学 \\ 工学部機械工学科 \\ サステイナブルマネジメント研究室 \\ Sustainable Management Laboratory Department of Mechanical Engineering, School of Engineering, Tokyo University of Technology}

\section{1. 大学の概要}

東京工科大学（以下、本学）は1986年の開学以来「実 学主義」を教育の柱としていますが、2015年4月に新設さ れた工学部では、革新的な技術と積極果敢な人材を輩出す る教育と研究を通じて、Sustainable Developmentの理念 を高度に具体化したサステイナブル社会（Sustainable Society）の実現に貢献するサステイナブル工学 (Sustainable Engineering) を追究するという目標を掲げ ました。

ここでいうサステイナブル社会とは、本学において技術 や製品のサステイナビリティを学問として扱う際のフレー ムワークとして位置づけたもので、図1に示すように、地 球システムに対しては「環境との調和（Planet）」を、人 間システムには「生活の質の向上 (People)」を、社会シ ステムには「経済の活性化 (Prosperity)」をそれぞれの 重要な視点として定めた社会だと考えています。そして、 これら3つの視点のバランスを良好に保ちながら、 Sustainable Developmentに向けて進化させ続けることを 新しい工学部の教育や研究における全体目標（ビジョン） として定めました。ちなみに本学では、Planet、People、
Prosperityの頭文字をとり、親しみやすさも考慮して「三 つのP」と称しています。

新工学部には機械工学科、電気電子工学科、応用化学科 の三学科が設置されましたが、サステイナブル工学に関連 した三学科共通の講義や演習科目を段階的に組み込むとと もに、学生全員が企業等に一定期間（8週間程度）在籍し て実際の研究開発業務などに従事する「コーオプ実習」を 中心とする「コーオプ教育 (Cooperative Education)」を 同時進行させるなど、実社会との連携を密に保ちながら、 三学科が一体となってサステイナブル工学を実践していく ためのカリキュラムを構成しています。

\section{2. 本研究室の概要}

こうしたなか、本研究室はその名も「サステイナブルマ ネジメント研究室」と銘打ち、新工学部が標榜するサステ イナブル工学教育を色濃く反映させた形で、工学部創設の 1 年前に設置されました。工学部はまだ 2 年生までしかい ませんので、現在は筆者の旧所属であるコンピュータサイ エンス学部の 4 年生 15 名が在籍し、卒業研究に取り組んで います。本年 3 月に初めて 10 名の卒業生を輩出したという 状況であり、研究もまだまだ緒に就いたばかりですが、従 来にない新たな分野の開拓に向け奮闘しているところです。

研究テーマとしては、上記の 3つの P (Planet、People、 Prosperity）を同時に考慮した技術開発を可能とする設計 方法論を追究しています。より具体的には、ライフサイク ル思考に基づき、製品の環境側面、機能・性能、経済効果 等を評価して総合的なサステイナビリティの向上を図るデ ザインプロセスを確立するため、概念設計、実体設計、詳 細設計のそれぞれにおいて設計者を支援できるような各種 方法論について研究しています。

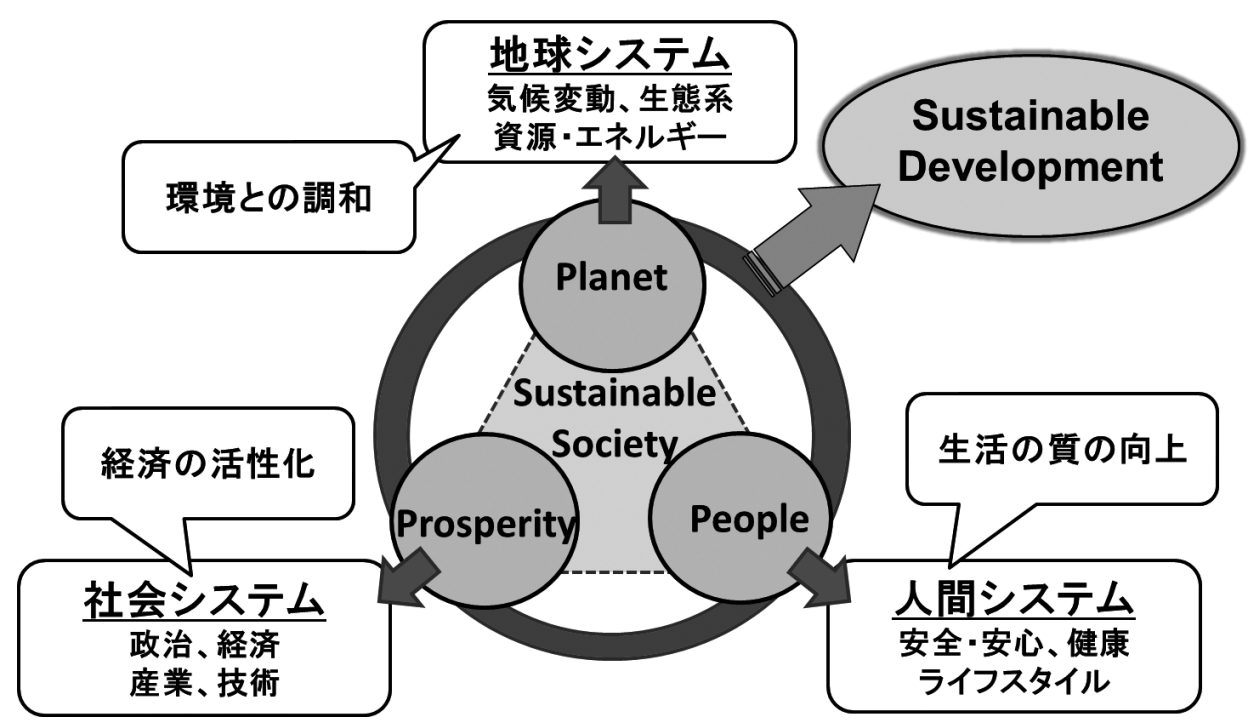

図1 サステイナブル社会の重要な視点 
研究室への配属にあたっては、「世の中を良くしたい学 生」「自ら研究を進めていく熱意と行動力のある学生」「サ ステイナブルマネジメントって言われてもよくわからない けど面白そうだなと思う学生」を募集していますが、要は、 やる気があれば誰でも OK、という非常に大らかな研究室 です。配属は 3 年生の後期からであり、まずはLCAの基 礎等をゼミ形式で半年間勉強します。そして、4年生に進 級後、次章に述べる大テーマの中から適宜個別テーマを設 定し、1年をかけて卒業研究に取り組みます。スケジュー ルは基本的に以下のような具合に進められています。

-4 5月：研究準備（文献調查、事前検討、個別テー 又決定）

• 6〜 7月：研究着手（目標設定、資料収集、デー夕取 得、分析手法検討)

・8月：中間発表（テーマと取組内容の説明）

-9 12月 : 研究推進（データ取得、算定、結果検証、 評価手法改善)

・1月： まとめ(結論策定、論文執筆)

$\cdot 2 \sim 3$ 月：最終発表（研究成果の発表、卒業判定）

\section{3. 本研究室の研究テーマ}

3.1 ライフサイクルアセスメント手法を利用した先導設計

私たちが日常的に良く利用する製品のLCAを実施し、 その結果を用いて次期製品の環境負荷低隇案を考案すると ともにその検証を行って、概念設計時に役立つ先導設計の 研究を進めています。主に、産業環境管理協会製のLCA ソフトウェア「MiLCA」等を使用し、PC関連製品（周辺
機器）や家電製品を分解して詳細なLCAを実施します。 環境負荷の低減に関しては、LIME2による被害算定をべー スに改善案を検討するだけでなく、さらにその評価と考察 を行って論文として仕上げるようにしています。また、サ ステイナブル工学的な観点からは、環境側面以外にも経済 面や機能面での価值向上につながる改善提案も同時に検討 し、より多面的なサステイナビリティ評価を実践して、従 来とは一味違う LCAの応用展開を模索しています。

\section{2 サスティナビリティに配慮した材料選択}

実体設計においては、製品の構成材料のサステイナビリ テイ評価に基づく最適な材料の選択について研究していま す。機械設計における材料選択では、主にGranta Design 社製の材料選択ソフトウェア「CES EduPack」を用い、 製品やシステムの簡易的な LCAを並行させながら、その 製品に用いられる材料の特性、環境負荷、コスト等の評価 を実施しています。図2は、自転車のフレーム用材料とし て適用可能な金属（鉄、アルミニウム、チタン）、複合材 料（CFRP）、一般的な木材、および竹について、フレー ムの剛性と材料製造時の $\mathrm{CO}_{2}$ 排出量とを比較して示したグ ラフの一例です。グラフは両対数であり、斜線（傾き2) が各材料の環境性能（左上が良好）を表す等高線になって います。本研究では、評価材料が受ける負荷の様式や加工 される形状等を考慮しながら、各種材料の特性值やその他 の評価因子を設計要求から導出される関係式を用いて指標 化し、環境負荷との関連において相対的に評価しているの が特徵となります。

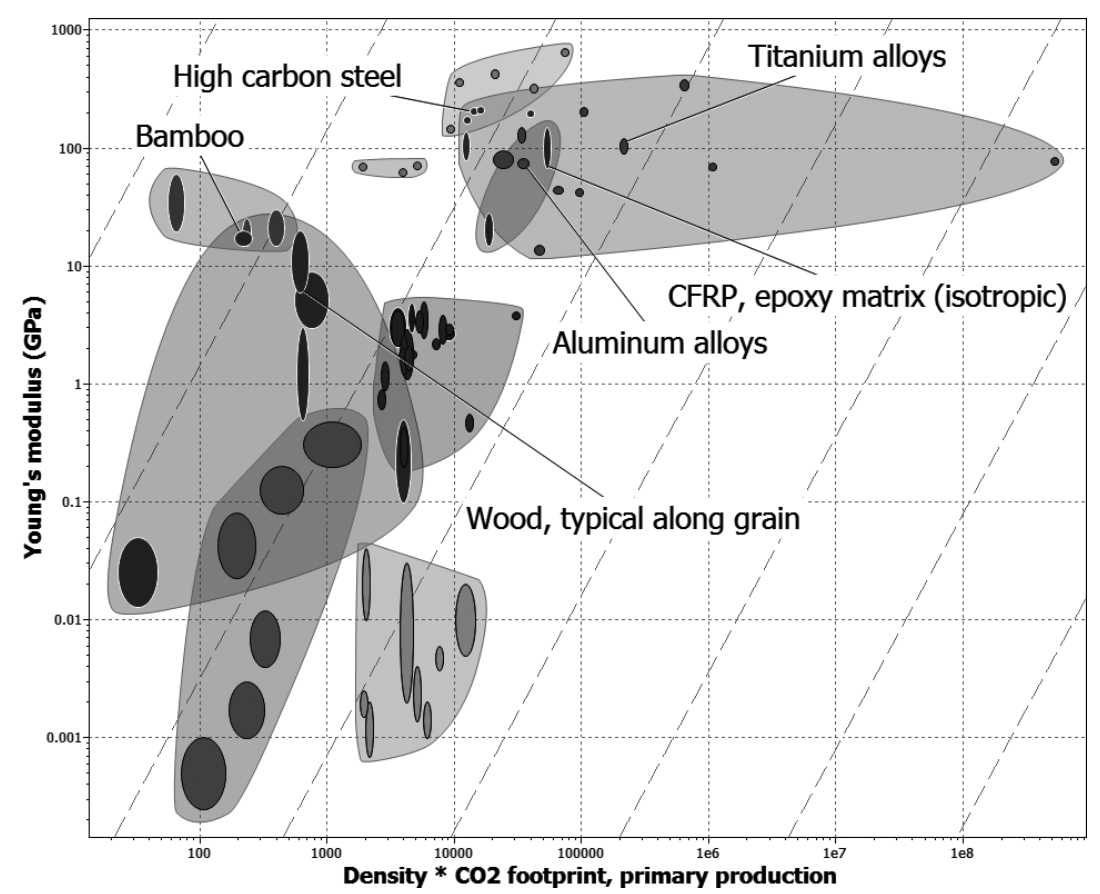




\section{3 環境経済効率指標の提案と評価}

詳細設計に関しては $3.1 て ゙$ 紹介した先導設計をさらに詳 細に実施していく予定ですが、その他の方向性として、社 会に送り出した技術や製品の包括的な影響（波及効果）を 評価する手法についても研究を進めています。昨年度の卒 業研究では、大学の 1 年間の活動による環境への影響につ いてエコロジカル・フットプリントを用いて算定し、その 改善提案をまとめた学生がいます。また、組織や地域の環 境負荷や経済活動を示す指標は数多くあり、これらを組み 合わせた指標としては国や地域のGDPあたりのエネル ギー総供給量を示す「エネルギー生産効率」が一般的です が、この指標の環境側面にエコロジカル・フットプリント を適用した新経済効率指標を提案した学生もいます。さら に、統合指標による各種イベントの被害算定について取り 組んだ学生もいます。日本全国から観光地へ旅行する場合 の環境負荷、経済効果、そして時間や楽しさ、といった多 様な価值を算定して統合し、よりサステイナブルな旅行を 提案しようとする研究です。

\section{4. 今後の展開}

上記のように、現在のところ本研究室には他学部の学生 のみが所属しているという変則的な状態にありますが、サ ステイナブル社会の実現は本学の基本理念である「生活の 質の向上と技術の発展に貢献する」を体現する「実学主義」 そのものであるとして、工学部だけでなく全学部が共通し て追究すべき到達点と捉えており、問題はありません。

サステイナブル工学は、地球システムの保全、人間シス テムの品質向上、そして社会システムの繁栄を同時に実現 し、人類全体のSustainable Developmentに貢献しょうと する学際的、横断的な学問です。したがって、各専門領域 の知識体系に依拠しながらも、従来の視座から大きく踏み 出した教育・研究活動を展開して、革新的な技術と創造的 な技術者を育成していかなければなりません。新工学部で は、個々の研究活動においてサステイナブル工学を意識し たテーマを数多く取り上げるとともに、他学部の教員と協 力して新エネルギー関連の共同プロジェクトを推進するな ど、教育面以外でもその実践に努めているところですが、 本研究室はその中心的存在となってサステイナブル工学の 実践に邁進していきたいと考えています。

\section{連絡先}

東京工科大学 工学部機械工学科 教授 芝池成人 shibaikenr@stf.teu.ac.jp 